\title{
Evaluation of physico-chemical characters and processing quality of some tomato hybrids
}

\author{
JAHANGIR KABIR* and N. SAMIR DHARMARAJII \\ Department of Post Harvest Technologyof Horticultural Crops, Faculty of Horticulture, Bidhan Chandra Krishi ViswaVidyalaya, \\ Mohanpur, NADIA (W.B.) INDIA \\ Email: j_kabir@rediffmail.com \\ *Author for Correspondence \\ Research chronicle : Received : 01.04.2015; Revised : 23.04.2015; Accepted : 05.05.2015
}

\begin{abstract}
SUMMARY :
Nine new hybrids of tomato namely NBH-Shakti-2005, NBH-666, NBH-Deshi number-1, NBH-Tripti2010, NBH-3355, NBH-333, SNTH-1, SNTH-2 and SNTH-3 were evaluated for various physicochemical characteristics and its suitability for processing into puree. The changes in quality characteristics of puree were studied in storage in ambient condition (Max. temp. $22.1^{\circ} \mathrm{C}$ to $38.9^{\circ} \mathrm{C}$; Min. temp. $14.3^{\circ} \mathrm{C}$ to $26.7^{\circ} \mathrm{C}$ and R.H. 31 to $93 \%$ ). Average length, diameter and weight ranged from 4.29 to $7.07 \mathrm{~cm}, 4.89$ to $5.56 \mathrm{~cm}$ and 71.15 to $104.36 \mathrm{~g}$, respectively. Higher fruit weight of NBH-666 (104.36g) and NBH-3355 (101.66g) is accompanied by large fruit size $(5.05 \mathrm{~cm}$ length, $5.56 \mathrm{~cm}$ diameter and $7.07 \mathrm{~cm}$ length, $4.89 \mathrm{~cm}$ diameter, respectively) compared to other varieties. Among the 9 hybrid varieties studies the variety SNTH-3 and NBH-Shakti-2005 were significantly less in weight and size. Locule number varied from 2.16 (in NBH-333) to 4.41 (in SNTH-1). In general, firmness of the hybrid varieties NBH-Tripti-2010, NBH-3355, NBH-333 and NBH-666 were high $\left(>1 \mathrm{~kg} / \mathrm{cm}^{2}\right)$ while that of NBH-Shakti-2005 and SNTH-3 were low compared to other varieties. Juice yield was high in SNTH3, SNTH-2, SNTH-1, NBH-3355, NBH-Tripti-2010 and NBH-Deshi number-1 (above 80\%). TSS content was high in NBH-Deshi number-1, SNTH-3 and SNTH-2 ( $>4^{\circ}$ Brix). Acidity and $\mathrm{pH}$ ranged from 0.26 (in NBH-333) to 0.53 (in SNTH-2) and 4.07 (in SNTH-2) to 4.43 (in NBH-333). Among the hybrids lycopene content was high in NBH-666 $(2.56 \mathrm{mg} / 100 \mathrm{~g})$, NBH-3355 $(2.38 \mathrm{mg} / 100 \mathrm{~g})$ and NBH-Shakti$2005(2.02 \mathrm{mg} / 100 \mathrm{~g})$ while lycopene content of NBH-Deshi number- 1 was least $(0.95 \mathrm{mg} / 100 \mathrm{~g})$. After preparation of puree, quality analysis and sensory evaluation revealed that NBH-666 and SNTH-1 were superior for processing, since these varieties possess higher chemical composition and scored high value for colour, flavour, consistency and overall acceptability score. Next preference can go to NBH-333 and SNTH-2. In storage however, the quality of puree deteriorated and after four months only the variety NBH-666 and NBH-333 retained the maximum colour, consistency, flavour and overall acceptability (total) as revealed from sensory score.
\end{abstract}

KEY WORDS : Physico-chemical characters, Processing quality of tomato

How to cite this paper : Kabir, Jahangir and Dharmarajii, N. Samir (2015). Evaluation of physico-chemical characters and processing quality of some tomato hybrids. Internat. J. Proc. \& Post Harvest Technol., 6 (1) : 54-61. 